gretted as especially the dextrin and wort would have introduced colloidal constituents which would in all probability have brought out more strongly the effect of adsorption which phenomenon must of necessity be associated with the changes of the relation of the solution and the pulp.

This investigation was undertaken solely for the purpose of finding conditions which would make it possible to obtain definite and uniform results for the extract in malt, more particularly for the coarse grindings. Although the result may not stand for a completed reaction but rather the attainment of an equilibrium between the solution and the insoluble pulp the method suggested gives results far more uniform than any method heretofore proposed.

ST. L.ouis, Mo.

[CONTRIBUTION FROM THE BUREAU OF CHEMISTRY, U. S. DEPARTMENT OF AGRICULTLRE, SUGAR LABORATORY.]

\title{
THE ESTIMATION OF DRY SUBSTANCE BY THE REFRACTOMETER IN LIQUID SACCHARINE FOOD PRODUCTS. ${ }^{1}$
}

BY A HUGH BRYAN

Received July 8, rgo8.

The Abbé heatable prism refractometer has come into use in England and on the continent for determining the dry substance content of sugar house products. On account of its ease of manipulation, and the accuracy of the readings as compared with actual dry substance, it has grown into favor. In I906, Tolman and Smith ${ }^{2}$ found that for practical purposes all sugars have the same index of refraction for the same concentration. They prepared a table for whole percentages of sucrose, giving the index of refraction taken at $20^{\circ}$. From their work, they came to the conclusion that the refractometer is a satisfactory instrument for determining the soluble carbohydrates in solution under the same conditions as those under which specific gravity can be used. In the same year Hugh Main, chemist of the Tate Refinery, London, England, called the attention of Drs. Wiechmann, Geerligs and Herzfeld, to the employment of the refractometer in estimating dry substance in refinery products. He had prepared a table from which the per cent. of water could be obtained from the refractive index. This table and his work were not published until $1907 .^{3}$ He found the readings accurate to $0 . I$ per cent. as compared with the usual methods of estimating water in sirups by drying on sand. Prinsen Geerligs, ${ }^{4}$ at the suggestion of the above author,

1 Published by permission of the Secretary of Agriculture.

2 This Journal, 28, 1476 (1906).

Intern. Sugar Journal, 9, 481 (1907).

Ibid., 10, 68.(1908). 
tried this instrument on cane sugar house products. He prepared a table of dry substance from the refractive index taken at $28^{\circ}$; also a table of corrections when taken at other temperatures. These are given in the paper. As it is chiefly the salts which in the determination of the degrees Brix, are the main cause of cliference between this and the actual dry substance, he decided to try solutions of difierent salts with the refractometer. As a result of numerous experiments, he found that with equal concentration, the calcium salts have a higher index than sucrose, that sodium salts have rather equal indices, while those of potash salts are lower. He tried, also, the refractive index of products coming from the decomposition of invert sugar by lime and alkalies and also the total non-sugar left behind by molasses after fermentation and distilling. With these substances, when mixed with sucrose, the dry substance by desiccation agrees very closely with that by the refractive index. In an examination of the final molasses of numerous cane houses, he found the dry substance by refractive index to agree very well with that by desiccation. The greatest divergence was 2.25 per cent. Iidmund o. von Lippman' has published results of trials of this instrument in beet sugar houses. The products examined were those which occur throughout the house. In the purer products the difference between the actual dry substance and dry substance by refractometer are very small, while in the final molasses these differences are slightly more. Yet in these latter cases, the widest difference does not make more than 1.5 per cent. difference in purity, and the average is under 0.5 per cent. difference. As compared with Brix reading (by pycnometer or spindle), the refractive index, in every case, is much nearer the actual dry substance. Where the products are rery dark in color, and an end-point in reading is hard to obtain or where the sample under examination contains crystals of sugar the sample can be diluted half and the reading made. The dry substance, when calculated from the half dilution, is nearer the actual dry substance than when undiluted. He used Mains's tables.

The purpose of this paper is to give results of determinations of dry substance, using this instrument along with the actual dry substance in honeys, sirups, molasses, etc. Comparison of results whose readings were made at different temperatures, showed the table of corrections to be as near correct as one could desire, so for most work the table of Geerligs is most available. The method used for determination of actual dry substance was the one ordinarily used for sugar products, viz., drying to constant weight of 3 to 5 grams on Io to 15 grams of sand in a flat-bottomed dish at $70^{\circ}$ in a vacumm oven. The drying was considered finished when the difference between two successive weighings,

${ }^{1}$ Deut. Zuckerind, 33, 106, 174 and 244 (1908). 


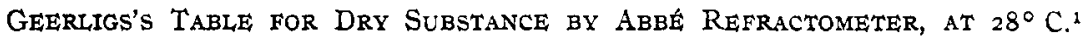

\begin{tabular}{|c|c|c|c|c|c|c|c|}
\hline \multirow{2}{*}{$\begin{array}{l}\text { Index. } \\
\text { I. } 3335\end{array}$} & \multirow{2}{*}{$\begin{array}{c}\text { Dry } \\
\text { sub- } \\
\text { stance. } \\
\text { Per } \\
\text { cent. } \\
I\end{array}$} & \multicolumn{2}{|c|}{ Decimals. } & \multirow{2}{*}{ Index. } & \multirow{2}{*}{\begin{tabular}{c}
$\begin{array}{c}\text { Dry } \\
\text { sub. } \\
\text { stance. } \\
\text { Per } \\
\text { cent. }\end{array}$ \\
\hdashline 46
\end{tabular}} & \multicolumn{2}{|c|}{ Decimals. } \\
\hline & & $0.000 \mathrm{I}=0.05$ & $0.0010=0.75$ & & & $0.0005=0.25$ & $0.0016=0.8$ \\
\hline I. 3349 & 2 & $0.0002=0 . I$ & $0.001 \mathrm{I}=0.8$ & I. 4124 & 47 & $0.0006=0.3$ & $0.0017=0.85$ \\
\hline I. 3364 & 3 & $0.000 .3=0.2$ & $0.0012=0.8$ & I.4I 45 & 48 & $0.0007=0.35$ & $0.0018=0.9$ \\
\hline I. 3379 & 4 & $0.0004=0.25$ & $0.0013=0.85$ & I. 4 I66 & 49 & $0.0008=0.4$ & $0.0019=0.95$ \\
\hline$x .3394$ & 5 & $0.000 .5=0.3$ & $0.0014=0.9$ & I. 4 I 86 & 50 & $0.0009=0.45$ & $0.0020=1.0$ \\
\hline I. 3409 & 6 & $0.0006=0.4$ & $0.0015=1.0$ & I. 4207 & $5 I$ & $0.0010=0.5$ & $0.0021=1.0$ \\
\hline I. 3424 & 7 & $0.0007=0.5$ & & I. 4228 & $5^{2}$ & $0.0011=0.55$ & \\
\hline I. 3439 & 8 & $0.0008=0.6$ & & I. 4249 & 53 & & \\
\hline I. 3454 & 9 & $0.0009=0.7$ & & 1.4270 & 54 & & \\
\hline I. 3469 & Io & & & 1.4292 & 55 & $0.0001=0.05$ & $0.0013=0.55$ \\
\hline I. 3484 & I I & $0.000 \mathrm{I}=0.05$ & & I. 43 I 4 & 56 & $0.0002=0 . I$ & $0.0014=0.6$ \\
\hline 1.3500 & 12 & $0.0002=0.1$ & & I. 4337 & 57 & $0.0003=0 . I$ & $0.0015=0.65$ \\
\hline 1.3516 & I3 & $0.0003=0.2$ & & 1.4359 & 58 & $0.0004=0.15$ & $0.0016=0.7$ \\
\hline I. 3530 & I4 & $0.0004=0.25$ & & 1.4382 & 59 & $0.0005=0.2$ & $0.0017=0.75$ \\
\hline I. 3546 & 15 & $0.0005=0.3$ & & I. 4405 & 60 & $0.0006=0.25$ & $0.0018=0.8$ \\
\hline I. 3562 & 16 & $0.0006=0.4$ & & I. 4428 & $6 I$ & $0.0007=0.3$ & $0.0019=0.85$ \\
\hline I. $357^{8}$ & 17 & $0.0007=0.45$ & & I. 445 I & 62 & $0.0008=0.35$ & $0.0020=0.9$ \\
\hline I. 3594 & I 8 & $0.0008=0.5$ & & 1.4474 & 63 & $0.0009=0.4$ & $0.002 I=0.9$ \\
\hline I. $36 \mathrm{II}$ & 19 & $0.0009=0.6$ & & I. 4497 & 64 & $0.0010=0.45$ & $0.0022=0.95$ \\
\hline I. 3627 & 20 & $0.0010=0.65$ & & I. $45^{20}$ & 65 & $0.00 \mathrm{II}=0.5$ & $0.0023=1.0$ \\
\hline I. 3644 & 21 & $0.00 \mathrm{II}=0.7$ & & I. 4543 & 66 & $0.0012=0.5$ & $0.0024=1.0$ \\
\hline I. $366 \mathrm{I}$ & 22 & $0.0012=0.75$ & & 1.4567 & 67 & & \\
\hline I. 3678 & 23 & $0.00 \mathrm{r} 3=0.8$ & & I.4591 & 68 & & \\
\hline I. 3695 & 24 & $0.0014=0.85$ & & 1.4615 & 69 & & \\
\hline $\mathrm{x} .3712$ & 25 & $0.0015=0.9$ & & I. 4639 & 70 & & \\
\hline 1.3729 & 26 & $0.0016=0.95$ & & I. 4663 & 71 & & \\
\hline I. 3746 & 27 & $0.0001=0.05$ & $0.0012=0.6$ & I. 4687 & 72 & & \\
\hline I. 3764 & 28 & $0.00012=0 . I$ & $0.00 r_{3}=0.65$ & I. 47 II & 73 & $0.0001=0.0$ & $0.0015=0.55$ \\
\hline r. 3782 & 29 & $0.0003=0.15$ & $0.0014=0.7$ & I. 4736 & 74 & $0.0002=0.05$ & $0.0016=0.6$ \\
\hline $\begin{array}{l}\text { I. } 3800 \\
\text { I. } 3818\end{array}$ & $\begin{array}{l}30 \\
3 I\end{array}$ & $\begin{array}{l}0.0004=0.2 \\
0.0005=0.25\end{array}$ & $\begin{array}{l}0.0015=0.75 \\
0.0016=0.8\end{array}$ & $\mathrm{I} .476 \mathrm{I}$ & 75 & $0.0003=0 . I$ & $0.0017=0.65$ \\
\hline $\begin{array}{l}\text { I. } 38 \mathbf{1} 8 \\
\text { I. } 3836\end{array}$ & $\begin{array}{l}31 \\
32\end{array}$ & $\begin{array}{l}0.0005=0.25 \\
0.0006=0.3\end{array}$ & $\begin{array}{l}0.0016=0.8 \\
0.0017=0.85\end{array}$ & I. 4786 & 76 & $0.0004=0.15$ & $0.0018=0.65$ \\
\hline I. 3854 & 33 & $0.0007=0.35$ & $0.0018=0.9$ & $I .48 I I$ & 77 & $0.0005=0.2$ & $0.0019=0.7$ \\
\hline I. 3872 & 34 & $0.0008=0.4$ & $0.0019=0.95$ & I. 4836 & 78 & $0.0006=0.2$ & $0.0020=0.75$ \\
\hline $1 \cdot 3890$ & 35 & $0.0009=0.45$ & $0.0020=1.0$ & I. 4862 & 79 & $0.0007=0.25$ & $0.002 \mathrm{I}=0.8$ \\
\hline I . 3909 & 36 & $0.0010=0.5$ & $0.002 \mathrm{I}=\mathrm{I}, 0$ & I. 4888 & 80 & $0.0008=0.3$ & $0.0022=0.8$ \\
\hline I. 3928 & 37 & $0.001 \mathrm{I}=0.55$ & & I. 4914 & $8 I$ & $0.0009=0.35$ & $0.0023=0.85$ \\
\hline I. 3947 & 38 & & & I. 4940 & 82 & $0.0010=0.35$ & $0.0024=0.9$ \\
\hline I. 3966 & 39 & & & I. 4966 & 83 & $0.00 \mathrm{II}=0.4$ & $0.0025=0.9$ \\
\hline r. 3984 & 40 & & & I. 4992 & 84 & $0.0012=0.45$ & $0.0026=0.95$ \\
\hline I. 4003 & $4 I$ & & & I. 5019 & 85 & $0.0013=0.5$ & $0.0027=1.0$ \\
\hline x. 4023 & 42 & $0.000 \mathrm{I}=0.05$ & $0.0012=0.6$ & $\begin{array}{l}1.5040 \\
1.5073\end{array}$ & $\begin{array}{l}80 \\
87\end{array}$ & & \\
\hline I. 4043 & 43 & $0.0002=0.1$ & $0.00 I_{3}=0.65$ & I. 5100 & 88 & & \\
\hline I. 4063 & 44 & $0.0003=0.15$ & $0.00 I_{4}=0.7$ & 1.5127 & 89 & & \\
\hline I. 4083 & 45 & $0.0004=0.2$ & $0.0015=0.75$ & I. 5155 & 90 & & \\
\hline
\end{tabular}


TABLE OF CORRECTIONS IOOR THI: T'EMPERATURE.

Temper ature $\quad$ Dry substance.

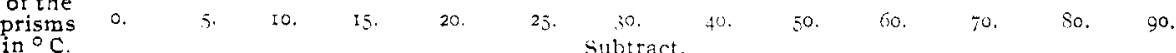

$\begin{array}{lllllllllllllll}20 & 0.53 & 0.54 & 0.55 & 0.56 & 0.57 & 0.58 & 0.60 & 0.62 & 0.64 & 0.62 & 0.61 & 0.60 & 0.58 \\ 21 & 0.46 & 0.47 & 0.48 & 0.49 & 0.50 & 0.51 & 0.52 & 0.54 & 0.56 & 0.54 & 0.53 & 0.52 & 0.50 \\ 22 & 0.40 & 0.41 & 0.42 & 0.42 & 0.43 & 0.44 & 0.45 & 0.47 & 0.48 & 0.47 & 0.46 & 0.45 & 0.44 \\ 23 & 0.33 & 0.33 & 0.34 & 0.35 & 0.36 & 0.37 & 0.35 & 0.39 & 0.40 & 0.39 & 0.38 & 0.38 & 0.38 \\ 24 & 0.26 & 0.26 & 0.27 & 0.28 & 0.28 & 0.29 & 0.30 & 0.31 & 0.32 & 0.31 & 0.31 & 0.30 & 0.30 \\ 25 & 0.20 & 0.20 & 0.21 & 0.21 & 0.22 & 0.22 & 0.23 & 0.23 & 0.24 & 0.23 & 0.23 & 0.23 & 0.22 \\ 26 & 0.12 & 0.12 & 0.13 & 0.14 & 0.14 & 0.14 & 0.15 & 0.15 & 0.16 & 0.16 & 0.16 & 0.15 & 0.14 \\ 27 & 0.07 & 0.07 & 0.07 & 0.07 & 0.07 & 0.07 & 0.08 & 0.08 & 0.08 & 0.08 & 0.08 & 0.08 & 0.07\end{array}$

$\begin{array}{lllllllllllllll}29 & 0.07 & 0.07 & 0.07 & 0.07 & 0.07 & 0.07 & 0.08 & 0.08 & 0.08 & 0.08 & 0.08 & 0.08 & 0.07\end{array}$

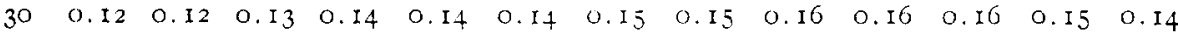

$\begin{array}{lllllllllllllll}31 & 0.20 & 0.20 & 0.21 & 0.21 & 0.22 & 0.22 & 0.23 & 0.23 & 0.2+ & 0.23 & 0.23 & 0.23 & 0.22\end{array}$

$\begin{array}{lllllllllllllll}32 & 0.26 & 0.26 & 0.27 & 0.28 & 0.28 & 0.29 & 0.30 & 0.31 & 0.32 & 0.31 & 0.31 & 0.30 & 0.30\end{array}$

$\begin{array}{llllllllllllll}33 & 0.33 & 0.33 & 0.34 & 0.35 & 0.36 & 0.37 & 0.38 & 0.39 & 0.40 & 0.39 & 0.38 & 0.38 & 0.38\end{array}$

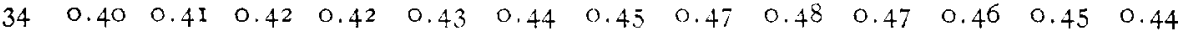

$\begin{array}{llllllllllllll}35 & 0.46 & 0.47 & 0.48 & 0.49 & 0.50 & 0.51 & 0.52 & 0.54 & 0.56 & 0.54 & 0.53 & 0.52 & 0.50\end{array}$

made after five hours' heating, was less than $3 \mathrm{mg}$. For lighting the instrument, a 32 candle-power electric lamp was focused on the mirror of the instrument. This was found to give a very satisfactory illumination.

The results of $d r y$ substance determinations by the two methods are now given on different substances:

Mapie Sirup.

$\begin{array}{cccc}\begin{array}{c}\text { Sample } \\ \text { No. }\end{array} & \text { Vacuum. } & \text { Rercellt. dry substance. } & \\ 5374 & 64.51 & 64.02 & \text { Difference. } \\ 5375 & 67.01 & 66.37 & -0.49 \\ 5535 & 67.33 & 66.73 & -0.64 \\ 5536 & 67.42 & 67.02 & -0.60 \\ 5537 & 66.72 & 66.52 & -0.40 \\ 5538 & 65.40 & 66.12 & -0.20 \\ 5569 & 66.81 & 66.55 & -0.72 \\ 5570 & 68.05 & 67.75 & -0.26 \\ 5571 & 68.72 & 68.35 & -0.30 \\ 5572 & 67.49 & 66.15 & -0.37 \\ 5574 & 65.47 & 64.70 & -1.34 \\ 5575 & 66.03 & 65.60 & -0.77 \\ 5577 & 65.56 & 64.75 & -0.43 \\ & & & -0.81\end{array}$

The actual dry substance is somewhat higher than by the refractometer in most cases. 
Cane Table Sirup.

\begin{tabular}{cccc}
$\begin{array}{c}\text { Sample } \\
\text { No. }\end{array}$ & \multicolumn{2}{c}{ Per cent. dry substance. } & \\
5471 & Vacuum. & Defractometer. & Difference. \\
5472 & 55.43 & 54.87 & -0.56 \\
5473 & 53.28 & 53.90 & +0.62 \\
5486 & 55.69 & 71.89 & -0.47 \\
5487 & 72.68 & 68.80 & -0.79 \\
5490 & 69.55 & 81.86 & -0.75 \\
5532 & 82.20 & 76.56 & -0.34 \\
5567 & 76.80 & 74.55 & -0.24 \\
5568 & 75.48 & 69.95 & -0.93 \\
5573 & 69.61 & 71.40 & +0.34 \\
& 71.24 & & +0.16
\end{tabular}

Here again the actual dry substance is higher than by the refractometer in most cases.

HONEYS.

\begin{tabular}{|c|c|c|c|}
\hline \multirow{2}{*}{$\begin{array}{l}\text { Sample } \\
\text { No. }\end{array}$} & \multicolumn{2}{|c|}{ Per cent. dry substance. } & \multirow[b]{2}{*}{ Difference. } \\
\hline & Vacuum. & Refractometer. & \\
\hline 4613 & 82.17 & 83.08 & +0.91 \\
\hline $537^{2}$ & $82 . I I$ & 80.85 & -1.26 \\
\hline 5373 & $83 \cdot 79$ & 84.00 & +0.21 \\
\hline 5516 & 82.07 & 79.70 & -2.37 \\
\hline 5517 & 84.82 & 82.30 & -2.52 \\
\hline 5518 & 78.48 & 76.35 & -2.13 \\
\hline 5519 & 82.40 & 80.95 & - I.45 \\
\hline $5510 a$ & 78.58 & $77 \cdot 43$ & - I.I5 \\
\hline $5510 b$ & 78.91 & 77.63 & -1.28 \\
\hline $5510 C$ & 79.23 & 77.92 & $-I \cdot 3 I$ \\
\hline $55 \mathrm{IOd}$ & 79.66 & 78.42 & -1.24 \\
\hline $5510 e$ & 79.66 & 78.10 & -1.56 \\
\hline $5510 f$ & 80.15 & 78.95 & -1.20 \\
\hline $55 I I a$ & 84.45 & 82.38 & -2.07 \\
\hline $55 I I b$ & 84.27 & 82.43 & $-\mathrm{I} .84$ \\
\hline $5511 C$ & $84 \cdot 49$ & 82.83 & $-\mathrm{I} .66$ \\
\hline $55 \mathrm{II} d$ & 84.45 & 82.63 & -1.82 \\
\hline $5511 e$ & $85 \cdot 50$ & 83.83 & -1.67 \\
\hline $55 \times 2 a$ & 79.19 & 77.22 & - I.97 \\
\hline $55 I 2 b$ & 79.27 & 77.62 & $-I .65$ \\
\hline $5512 C$ & $79.8 \mathrm{I}$ & 77.82 & -1.99 \\
\hline $5512 d$ & 80.29 & 78.42 & -1.87 \\
\hline $5512 e$ & 79.65 & 78.40 & -1.25 \\
\hline 55 I $2 f$ & 77.93 & 76.18 & - I. 75 \\
\hline
\end{tabular}

The differences noted here are much larger than with the other classes of substances examined. In only two cases was the dry substance by refractometer higher than the actual. It is a question whether the drying at $70^{\circ}$ releases all the water. Quite a number of analysts obtain the per cent. of moisture in honey by drying at boiling water temperature to 
constant weight. Some analysts report water in honey as loss in weight by drying in vacuum at $105^{\circ}$ to $110^{\circ}$. Utz, ${ }^{1}$ using Tolman and Smith's figures for dry substance from refractive index of honey, gives results within 0.2 per cent. of the dry substance obtained from specific gravity.

Glicose Sirty.

Two samples were examined: one of commercial glucose gave 84.97 per cent. actual dry substance and 85.24 per cent. by refractometer, an agreement within 0.27 per cent. The other, a table sirup of 71.63 per cent. actual dry substance and $7 r .90$ per cent. by the refractometer. These two methods give figures that agree very closely on this material.

Cane Molasses.

Sample

5369

5477

5478

5479

548 I

5498

5499

5500

5501

5502

5503

5504

5505

5506

5507

5508

5509
Per cent. dry substance.

\begin{tabular}{|c|c|c|}
\hline Vacuum & Refractometer. & Difference \\
\hline 75.67 & 76.26 & +0.59 \\
\hline $73.9^{6}$ & 73.58 & -0.38 \\
\hline 74.86 & 75.02 & +0.16 \\
\hline 75.11 & 75.50 & +0.39 \\
\hline 73.95 & 73.14 & $-0.8 \mathrm{I}$ \\
\hline 75.23 & 74.49 & -0.74 \\
\hline 75.61 & $74 \cdot 39$ & -1.22 \\
\hline 74.95 & 74.19 & -0.76 \\
\hline 74.04 & 73.54 & -0.50 \\
\hline 76.14 & 74.84 & $-1 \cdot 30$ \\
\hline 76.66 & 75.24 & -1.42 \\
\hline 76.40 & 75.49 & $-0.9 \mathrm{I}$ \\
\hline $7^{6.17}$ & 74.64 & -1.53 \\
\hline 74.06 & 72.84 & -1.22 \\
\hline $75 \cdot 73$ & $74 \cdot 54$ & - I. I9 \\
\hline 75.15 & 73.89 & - I. 26 \\
\hline 71.45 & 70.14 & $-1 \cdot 31$ \\
\hline
\end{tabular}

With the exception of three samples, all the actual dry substance determinations are higher than that by the refractometer.

Most of these samples were very dark in color and it was hard to obtain a clear line in the original sample, but with the half-diluted sample the reading was very easily accomplished. The differences between actual dry substances and dry substance from refractive index on the halfdiluted sample is, in most cases, very small. This fact was noted by von Lippman in his work on beet sugar products. This seems to point to the use of the half-diluted solution for the determination of dry substance in beet molasses. Lange ${ }^{2}$ recommends the following clarification for dark products: the addition of 2 to $3 \mathrm{cc}$. lead acetate solution to the 50 grams of molasses and make up with water to 100 grams. The small amount of the precipitant does not interfere with the determination, but

$1 \%$ angex. (hem., 21, 1319 (1908).

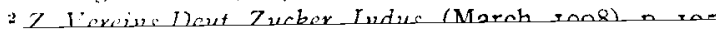


Beet Molasses.

\begin{tabular}{|c|c|c|c|c|c|}
\hline \multirow[b]{3}{*}{$\begin{array}{c}\text { Sample } \\
\text { No. }\end{array}$} & \multicolumn{3}{|c|}{ Per cent. dry substance. } & \multirow{2}{*}{\multicolumn{2}{|c|}{ Difference. }} \\
\hline & & \multicolumn{2}{|c|}{ Refractometer. } & & \\
\hline & Vacuum. & $\begin{array}{l}\text { Original } \\
\text { sample. }\end{array}$ & $\begin{array}{c}\text { Diluted } \\
\text { half. }\end{array}$ & $\begin{array}{l}\text { Original } \\
\text { sample. }\end{array}$ & $\begin{array}{c}\text { Dituted. } \\
\text { half.: }\end{array}$ \\
\hline 4685 & 69.09 & 68.35 & 68.70 & -0.74 & -0.39 \\
\hline 4686 & 82.54 & 81.73 & 81.80 & $-0.8 \mathrm{I}$ & -0.74 \\
\hline 4633 & 71.87 & 71.80 & 72.40 & -0.07 & +0.53 \\
\hline 4634 & 77.26 & 76.40 & $77 \cdot 70$ & -0.86 & +0.44 \\
\hline 4637 & 80.83 & 79.00 & $8 I, 10$ & -1.83 & +0.27 \\
\hline 4638 & 77.83 & 76.70 & 77.20 & - I.I3 & -0.63 \\
\hline 4649 & $79 . \mathrm{II}$ & 78.20 & 78.00 & $-0.9 \mathrm{I}$ & - I.II \\
\hline 4650 & $75 \cdot 55$ & 75.17 & 75.90 & -0.38 & +0.35 \\
\hline 4652 & 74.20 & 73.00 & $73 \cdot 70$ & -I.20 & -0.50 \\
\hline 4682 & 80.32 & 78.60 & 78.70 & -1.72 & -1.62 \\
\hline $4685 a$ & 68.73 & 68.17 & 68.70 & -0.56 & -0.03 \\
\hline $4686 b$ & 82.35 & 80.90 & 81.80 & $-\mathrm{I} .45$ & -0.55 \\
\hline 48 I 2 & 72.72 & 70.92 & 71.90 & $-\mathrm{I} .80$ & -0.82 \\
\hline $4^{8} \mathrm{I}_{3}$ & 78.70 & 77.20 & 77.80 & $-I .50$ & -0.90 \\
\hline 5579 & 80.35 & 79.20 & 80.60 & -I.I 5 & +0.25 \\
\hline
\end{tabular}

large quantities do. This was tried and found to give results as published, but the solutions were not much lighter in color. A much better procedure for dark solution, even in half dilution, is to add a few crystals of sodium hydrosulphite and shake. This bleaches the solution, and, from tests made, does not increase the refractive index when used in small quantities.

Comparison of the two methods given above with the Brix obtained by hydrometer or specific gravity showed the dry substance by refractive index to be nearer the actual dry substance than the Brix.

The specific gravity was determined on a few of the samples of each class and the results are recorded here.

Dry substance from

\begin{tabular}{|c|c|c|}
\hline Actual drying. & Refractorneter. & Spec. gravity. \\
\hline Maple sirup $\ldots \ldots \ldots \ldots \ldots \ldots 67.42$ & 67.02 & 68.83 \\
\hline Maple sirup $\ldots \ldots \ldots \ldots \ldots \ldots 66.72$ & 66.52 & 67.91 \\
\hline Cane $\operatorname{sirup} \ldots \ldots \ldots \ldots \ldots \ldots .20$ & $8 \mathrm{I} .86$ & 83.50 \\
\hline Cane sirup $\ldots \ldots \ldots \ldots \ldots \ldots . \ldots 5.43$ & 54.87 & 56.1 \\
\hline Cane $\operatorname{sirup} \ldots \ldots \ldots \ldots \ldots \ldots 72.68$ & 71.89 & 74.2 \\
\hline Glucose . . . . . . . . . . . . . . . . 84.97 & 85.24 & 82.65 \\
\hline Cane molasses. . . . . . . . . . 73.96 & $73 \cdot 58$ & $75 \cdot 70$ \\
\hline Cane molasses............. $75 \cdot 73$ & $74 \cdot 54$ & 78.25 \\
\hline Cane molasses. . . . . . . . . 76.66 & 75.24 & 77.85 \\
\hline Cane molasses...............76.40 & $75 \cdot 49$ & 78.20 \\
\hline Beet molasses. . . . . . . . . . 80.35 & 80.60 & 85.28 \\
\hline Beet molasses. . . . . . . . . & $8 \mathrm{I} .80$ & 84.75 \\
\hline 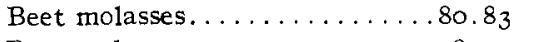 & $8 \mathrm{I} . \mathrm{IO}$ & 83.80 \\
\hline Beet molasses............78.70 & 77.80 & 84.00 \\
\hline
\end{tabular}


This has been noted by all analysts who have used the refractometer, so it can be seen that for dry substance determinations the refractometer has a place, and an important one. With its use one is able to obtain identical results on numerous samples of the same solution. This can not be said of the actual drying method. So many factors enter into this determination, that one may have results differing by as much as 0.7 per cent. when determining dry substance at different times on the same solution. This difference is often met with when working solutions containing large quantities of reducing sugars. There are also differences arising from the personal equation in the determination of dry substance on the same substance by actual drying; and again, food chemists vary as to their manipulation in this determination, so the results vary. By the use of the refractometer, most of these points are eliminated, and the results obtained are perfectly comparable, especially so after one has accustomed himself to the use of this instrument. The results of this work show very close agreement between the actual dry substance and dry substance by refractometer, except in case of honey. And also, the refractometer readings are nearer the actual dry substance in most cases than the dry substance by specific gravity. So this commends the use of this instrument. The speed with which a determination can be made, and the small quantity of substance required for a determination, also recommend this instrument. As regards the use of the instrument for determining the dry substance in honey, the question is receiving more attention by the author. But even with this class of substances, the results would be comparable by its use.

To the technical chemist, of a sugar house, the instrument appeals greatly. The ease of manipulation and accuracy as compared with the ordinary methods in vogue recommends its use. Purities obtained by the use of the dry substance from refractometer agree very closely with the "Real" purity. A table showing the three purities, both for the samples of cane and beet molasses, is given.

Purity of Cane Molasses, coming from using actual dry substance and dry substance by the refractometer, also Brix from specific gravity:

\begin{tabular}{ccccc} 
& & \multicolumn{3}{c}{ Purity from dry substance by } \\
No. & Percent. sugar. & Drying. & Refractometer. & Spec. gravity. \\
5369 & 34.6 & 45.72 & 45.37 & $\ldots$ \\
5477 & 46.3 & 62.60 & 62.92 & 61.17 \\
5478 & 45.7 & 61.05 & 60.92 & $\ldots$ \\
5479 & 46.1 & 61.38 & 61.06 & $\ldots$ \\
$548 \mathrm{I}$ & 46.0 & 62.20 & 62.89 & $\ldots$ \\
5498 & 47.8 & 63.55 & 64.16 & $\ldots$ \\
5499 & 34.7 & 45.89 & 46.64 & $\ldots$ \\
5500 & 44.5 & 59.37 & 59.98 & $\ldots$ \\
5501 & 38.1 & 51.46 & 51.81 & $\ldots$ \\
5502 & 1.2 & $\ldots .2$ & &
\end{tabular}




\begin{tabular}{ccccc} 
& & \multicolumn{3}{c}{ Putity from dry substance by } \\
\cline { 3 - 5 } No. & Percent. sugar. & Drying. & Refractometer. & Spec. gravity. \\
5503 & 44.6 & 58.18 & 59.27 & 57.29 \\
5504 & 39.0 & 51.05 & 51.66 & 49.87 \\
5505 & 44.0 & 57.77 & 58.95 & $\ldots$ \\
5506 & 47.9 & 64.66 & 65.76 & $\ldots$ \\
5507 & 32.2 & 42.52 & 43.20 & 41.15 \\
5508 & 46.7 & 62.14 & 63.20 & $\ldots$ \\
5509 & 26.9 & 37.65 & 38.35 & $\ldots$
\end{tabular}

Purity of beet molasses, coming from using actual dry substance and dry substance by refractometer in half dilution, also Brix from specific gravity.

Purity from dry substance by

$\begin{array}{lcccc}\text { No. } & \text { Per cent. sugar. } & \text { Actual drying. } & \text { Refraction. } & \text { Spec. gravity. } \\ 4685 & 42.09 & 60.92 & 61.28 & 56.4 \\ 4686 & 50.54 & 61.23 & 61.78 & 58.3 \\ 4633 & 48.15 & 67.00 & 66.50 & \ldots \\ 4634 & 52.15 & 67.50 & 67.12 & \ldots \\ 4637 & 52.56 & 65.03 & 64.81 & 62.0 \\ 4638 & 48.90 & 62.83 & 63.34 & \ldots \\ 4649 & 50.15 & 63.39 & 64.30 & \ldots \\ 4650 & 49.94 & 66.10 & 65.80 & \ldots \\ 4652 & 45.96 & 61.94 & 62.36 & \ldots \\ 4682 & 51.43 & 64.03 & 65.34 & \ldots \\ 4685 a & 39.39 & 57.31 & 57.34 & \ldots \\ 4686 a & 50.77 & 61.65 & 62.06 & 59.9 \\ 4812 & 41.57 & 57.17 & 57.82 & \ldots \\ 4813 & 52.19 & 66.31 & 67.08 & 57.4 \\ 5579 & 48.20 & 59.98 & 59.80 & 56.5\end{array}$

The purity by Brix determination is much lower than by the other two methods of determination. This fact is well known by all sugar chemists and introduces considerable error into factory control work. With the use of the refractometer, theoretically this error will be present to a slight extent, but in actual practice, I doubt whether there would be as large an error using dry substance by the refractometer as when using dry substance by actual drying, because the methods for actual drying as practiced are so crude.

[CONTRIBUTIONS FROM THE HAVEMEYER LABORATORIES OF COIUMBIA UNIVERSITY, No. I56.]

\section{THE DETECTION AND IDENTIFICATION OF CERTAIN REDUCING SUGARS BY CONDENSATION WITH p-BROM- BENZYLHYDRAZIDE.}

By E. C. KENDALL AND H. C. SHERMAN.

$\mathrm{Kahl}^{1}$ investigated the action of various hydrazides upon reducing

1 Ueber die Paarung von Säurehydraziden mit Zuckerarten. Inaug. Diss. Firehirex rans 